\title{
Resistance Status and Associated Resistance Mechanisms to Certain Insecticides in Rice Weevil Sitophilus oryzae (Coleoptera: Curculionidae)
}

\author{
Manal A. Attia ${ }^{* 1}$, Trandil F. Wahba ${ }^{1}$, Marwa I. Mackled ${ }^{2}$ and M. S. Shawir ${ }^{3}$ \\ ${ }^{1}$ Insecticide Bioassay Department, Central Agricultural Pesticides Lab. (CAPL), Agriculture Research \\ Center (ARC), 21616, Alexandria, Egypt \\ ${ }^{2}$ Department of stored product Pests, Plant Protection Institute, Agriculture Research Center (ARC), \\ Alexandria, Egypt \\ ${ }^{3}$ Pesticide Chemistry and technology Department, Faculty of Agriculture, Alexandria University, Elshatby, \\ Alexandria, Egypt \\ *Corresponding author: Manal A. Attia- manal.attia77@gmail.com \\ Plant protection Station, Agricultural Research Center (ARC), Sabahia, Baccous, 21616 Alexandria, Egypt.
}

\begin{abstract}
The rice weevil, Sitophilus oryzae (Coleoptera: Curculionidae) was collected from El-Behera governorate (EB). The first generation showed reduced susceptibility to deltamethrin and malathion compared with the laboratory susceptible strain (LS). Susceptibility test results (using LS colony as a reference strain) indicated that EB strain has relative toxicity ratio, $R_{50}$ and $R_{90}$ of 16.64 and 9.08 for malathion. Although, EB strain was tolerant to deltamethrin with $R_{50}$ of 5.2, it was marginally resistant to cypermethrin and entirely susceptible to permethrin. The biochemical results showed elevation in the activity of total esterase (ES), carboxylesterase (CE) and glutathione $S$ - transferase (GST) which suggested that the metabolic resistance may has a key function in this population. Furthermore, acetylycholinesterase (AChE) activity in EB strain was 3.52 times higher compared with LS strain which pointed the insensitivity of AChE in EB strain. Moreover, esterase analysis indicated genetic polymorphism between EB and LS populations which might be attributed to selection pressure due to continuous exposure to insecticides. This study suggested the existence of malathion and deltamethrin resistance in EB strain which might be a consequence of biochemical alterations. The results of current study indicate the importance of continuous monitoring of resistance of stored product insect pests to plan successful management strategies.
\end{abstract}

Keywords: insecticide resistance, metabolic resistance, esterase, Sitophilus oryzae, malathion.

\section{INTRODUCTION}

The rice weevil, Sitophilus oryzae (L.) (Coleoptera: Curculionidae) is one of the most destructive primary pests which can easily infest intact cereal seeds, i.e, rice, wheat, maize and barley or non-cereals like split peas and pasta. It may attack cereal plants in the fields. The existence of this insect causes weight loss, fungi and mites infestation thus decrease the grain quantity and quality through increasing free fatty acids contents (CABI, 2017). The weight loss interrelated to $S$. oryzae and $S$. granarius, under natural conditions estimated in rice, ranged (56 - 74\%) (Koura and ElHalfawy, 1972). Furthermore, wheat storage in Egypt for significant assorted periods is crucial because the national production provides only $55 \%$ of the total requirements (FAO, 2006). The majority of the Egyptian storage system is conventional as 1.6 million tonnes stored in "Shona" (FAO, 2015) and around $20-30 \%$ of wheat lost during storage (Wally, 2014) which demand grain protection measures that rely markedly on chemical pesticides. Chemical pesticides were employed in stored grain protection since 1945 started with lindane followed by malathion in 1958 and then other organophosphate and pyrethroids (Kljajić and Perić, 2007). The continuous use of insecticides to afford lasting grain protection led to development of insecticide resistance in stored product insects (Kljajić and Perić, 2009) and (Hagstrum and Phillips, 2017). Insecticide resistance in stored product insects is a growing problem which was first reported near the beginning of 1960's once resistance to malathion detected in the red flour beetle, Tribolium castaneum (Herbst) in Nigeria, the United States, Egypt, Australia (Zettler, 1974) and Kenya (Beeman and Nanis, 1986). Moreover, S. oryzae developed resistance to organophosphate pesticides (Julio et al., 2017) as well pyrethroid insecticides (Heather, 1986 and Athanassiou et al., 2004). According to Arthropod Pesticide Resistance Database, up to date, there are nine cases of malathion resistance were reported in $S$. orayze populations among 38 cases (APRD, 2017). Susceptibility shift in an insect populations is a demanding limitation factor in chemical control that directly leads to increase application rates and treatments frequency which have harmful impact on economic, environment and human health (Hagstrum and Phillips, 2017). Therefore, the regular evaluation of insect population susceptibility 
is considered the foremost step in a successful control program. The present work aimed to evaluate the susceptibility of $S$. oryzae population collected from Elbehera, Egypt to malathion and certain pyrethroids as well to investigate the possible associated mechanism (s) of resistance in this strain.

\section{MATERIALS AND METHODS}

Insect strains: A laboratory susceptible strain (LS) of Sitophilus oryzae has been continuously reared in the laboratory for more than eight years at Faculty of Agriculture, Alexandria University. Adult beetles (2-3 weeks old) reared on whole wheat under stander conditions of $28{ }^{\circ} \mathrm{C} \pm 1$, RH of $70 \pm 5$ and photoperiod L/D of 12:12hr (Strong et al, 1967).

El-Behera strain (EB): samples of rice were purchased and collected from markets located in ElBehara Governorate, Egypt during summer season of 2016. Samples were mixed then the adults of $S$. oryzae were separated and transferred to sterilized whole wheat for eggs lying. After 7 days, the adults were removed and the media were stored at the standard rearing conditions until adult's emergency. Adults of 2-3 weeks old of the first generation were used for the present study.

Insecticides: Deltamethrin (98\%), permethrin, cypermethrin (96.62\%) and malathion (95\%) as technical grad samples of pesticides were obtained from the National Company for Agrochemicals \& Investment (Agrochem.), Egypt.

Chemicals: All chemicals used were purchased from Sigma/Aldrich Company

Susceptibility test

Pesticide residual film technique was preformed according to (FAO, 1974) to determine the resistance level in EB colony comparing with the LS strain as a reference strain. A series of insecticide concentrations dissolved in acetone $(1 \mathrm{ml})$ were applied onto Whatman paper No. 1 which placed in Petri dishes $(9 \mathrm{~cm})$ and set aside for $15 \mathrm{~min}$ to allow solvent evaporation. Twenty adults (2-3 weeks old) from both colonies were transferred to each Petridish. Each concentration was replicated three times and kept at $28{ }^{\circ} \mathrm{C} \pm 1,70 \% \pm 5 \mathrm{RH}$ and $12: 12 \mathrm{hr}$ photoperiod]. Mortality percentages were recorded after $24 \mathrm{hr}$ of treatment and $\mathrm{LC}_{50}$ and $\mathrm{LC}_{90}$ values and their confidence limits were calculated according to (Finney, 1971) using Ld-p Line ${ }^{\circledR}$ (a software program).

\section{Crude Enzyme preparation}

Adult beetles (2-3 weeks old) from each colony were homogenized in ice cold $0.1 \mathrm{M}$ sodium phosphate buffer ( $\mathrm{pH}$ 7.4) contains $0.5 \mathrm{mM}$ EDTA $(1: 10 \mathrm{w} / \mathrm{v})$ for $20 \mathrm{sec}$ two times. Then, the homogenates were centrifuged at $1000 \mathrm{rpm}$ for 15 min. After centrifugation, the resultant supernatants were filtrated through glass wool and recenterifugated at $10,000 \mathrm{rpm}$ for $30 \mathrm{~min}$. The resultant supernatants were used for the biochemical assays.

Total esterase activity: The assay was performed according to (Van Asperen 1962). The reaction mixture $(2.5 \mathrm{ml})$ contains: $30 \mu \mathrm{l}$ crude enzyme, sodium phosphate buffer $(0.1 \mathrm{M} \mathrm{pH} 7.4)$ and fast blue dye solution [2.15 $\mathrm{mM} \alpha$-naphthayl-acetate dissolved in acetone and mixed with $1.2 \mathrm{mM}$ fast blue B slate (O-dianisidine) in phosphate buffer]. Absorbance was measured at wave length of $\lambda_{450} \mathrm{~nm}$ after 15 minutes incubation period. The specific activity was expressed as $\Delta$ Optical density (OD) at $\lambda_{450} / \mathrm{mg}$ protein $/ \mathrm{min}$.

Carboxylesterase (CE) activity: CE was determined according to (Mendoza et al., 1971). A reaction was initiated by adding $0.02 \mathrm{M}$ of indophenyl acetate dissolved immediately in acetone to solution of 0.05 $\mathrm{M}$ tris- $\mathrm{HCl}$ and $30 \mu \mathrm{l}$ of the crude enzyme. The absorbance was measured at $\lambda_{412} \mathrm{~nm}$ after incubation at $37^{\circ} \mathrm{C}$ for $15 \mathrm{~min}$. The specific activity was calculated as $\Delta$ Optical density (OD) at $\lambda_{412} / \mathrm{mg}$ protein/min.

Glutathion-S- transferease (GST) activity: GST was determined according to the method of ( Vessey and Boyer, 1984) The reaction mixture consists of $1.45 \mathrm{ml} 5 \mathrm{mM}$ glutathione in $0.1 \mathrm{M}$ sodium phosphate buffer $\mathrm{pH} 7.5,20 \mu \mathrm{l}$ of 1-chloro2, 4-dinitrobenzene (CDNB $75 \mathrm{mM}$ ) in absolute ethanol and $30 \mu \mathrm{l}$ of the crude enzyme. The changes of absorbance were measured continuously at $\lambda_{345} \mathrm{~nm}$. The activity was expressed as $\Delta$ Optical density (OD) at $\lambda_{345} / \mathrm{mg}$ protein $/ \mathrm{min}$.

Acetylcholinesterase (AChE) activity: AChE was determined according to (Ellman et al. 1961). A three $\mathrm{ml}$ total volume reaction solution was containing: $10 \mathrm{mM}$ dithiobis-(2 nitrobenzoic acid dissolved in $100 \mathrm{mM}$ phosphate buffer $\mathrm{pH} 7.4,75$ $\mathrm{mM}$ acetylthiocholine iodide and $50 \mu \mathrm{l}$ of crude enzyme. After $30 \mathrm{~min}$ incubation at $37^{\circ} \mathrm{C}$ the optical density was measured at $\lambda_{412} \mathrm{~nm}$. The activity was calculated as $\Delta \mathrm{OD}$ at $\lambda_{412} / \mathrm{min} / \mathrm{mg}$ protein.

Protein concentration: Protein was measured according to the method of (Lowry et al., 1951) using bovine serum albumin (BSA) as a standard.

Esterase izozymes profile: Agar-starch-polyvinyl pyrolidine (PVP) poly vinyl gel electrophoresis was carried out according to the procedures described by (Shaw and Prasad, 1970). The gel plates $[20 * 30 \mathrm{~cm}$ and thickness of $0.9 \mathrm{~mm}$ ] consisting of PVP $1 \mathrm{~g}$ and $1 \mathrm{~g}$ hydrolyzed starch dissolved in $10 \mathrm{ml}$ electrode buffer $[(0.07 \mathrm{M}$ Tris and citric acid $0.007 \mathrm{M}$ $(\mathrm{pH}=8.3)]$ and $90 \mathrm{ml}$ distilled water. Electrophoresis runs were performed at $4^{\circ} \mathrm{C}$ and $250 \mathrm{mV}$ constant for 90 minutes. After the full set run, gels were incubated for $30 \mathrm{~min}$ at room temperature and complete darkness in the staining buffer $[100 \mathrm{ml}$ phosphate buffer $(\mathrm{pH}=7.0)$ containing $50 \mathrm{mg}$ fast blue RR salt (bis (4-benzamido-2,5dimethoxybenzenediazonium) zinc (II) chloride ) 
and $20 \mathrm{mg} \alpha$-naphthyl acetate, and $20 \mathrm{mg} \beta$ naphthyl acetate dissolved in $1 \mathrm{ml}$ acetone]. Then, the plates were distained in distilled water until a clear background was appeared. The plates were subjected to analysis using PAST: Paleontological Statistics Software (http://palaeo-electronica.org).

\section{RESULTS}

Bioassay: The data of susceptibility tests showed that EB strain was significantly resistant to malathion compared with the LS strain with resistance ratios at $\mathrm{LC}_{50}$ (defined as $\mathrm{LC}_{50}$ resistant $(\mathrm{EB}) / \mathrm{LC}_{50}$ susceptible (LS) $=\mathrm{RR}_{50}$ ) of 9.08 fold (Table1) and it was vigorously tolerant to deltamethrin $\left(\mathrm{RR}_{50}=5.02\right.$ fold $)$. Furthermore, the confidence limits of $\mathrm{LC}_{50}$, $\mathrm{s}$ were not overlapped. As a consequence of the different slopes and intercepts of deltamethrin and malathion regression lines of both strains, the $\mathrm{RR}$ ratios were varied at $\mathrm{LC}_{90}$ for both insecticides (Fig 1: c, d). The deltamethrin $\mathrm{RR}_{90}$ decreased to 2.98 fold compared with $\mathrm{RR}_{50}$, while a distinct increase was recorded with malathon $\left(\mathrm{RR}_{90} 16.64\right.$ fold). Meanwhile, ES strain was slightly tolerant to cypermethin compared with the LS strain with $\mathrm{RR}_{50} 1.79$ fold. The regression lines of both strains were crossed (Fig 1: a) and both the slopes and intercepts were not equals. The $R R_{50}$ and $\mathrm{RR}_{90}$ were greatly changed from 1.79 to 9.9 fold, respectively. On the other hand, permethrin did not show any distinction between both strains because the $\mathrm{LC}_{50}$ were 0.778 for LS and 0.720 for EB with overlapped confidence limits at (0.05) significance level and approximately identical regression lines given that both intercepts and slopes were not varied considerably (Fig 1:b).

Enzymes activity: Biochemical data are summarized in Table (2). The detoxification enzymes activity in adults of ES strain compared with LS one showed significant higher activity of carboxylesterase, (CE) $\left(3.95 * 10^{-3}\right.$ and $\left.1.16^{*} 10^{-3}\right) \Delta$ OD at $\lambda_{412} / \mathrm{mg}$ protein $/ \mathrm{min}$, respectively. As well, the same trend was recorded with total esterase and GST, since the activity were $\left(1.2 * 10^{-2}\right.$ and $\left.5.3 * 10^{-2}\right)$ $\Delta \mathrm{OD}$ at $\lambda_{450} / \mathrm{mg}$ protein $/ \mathrm{min}$ and $\left(6.44 * 10^{-3}\right.$ and $\left.2.42 * 10^{-2}\right) \Delta \mathrm{OD}$ at $\lambda_{345} / \mathrm{mg}$ protein $/ \mathrm{min}$ in LS and ES strains, respectively. Moreover, significant difference also was found in activity of the target site enzyme (AChE) between LS $\left(8.41 * 10^{-4}\right)$ and ES $\left(2.96^{*} 10^{-3}\right) \quad \triangle \mathrm{OD}$ at $\lambda_{412} / \mathrm{min} / \mathrm{mg}$ protein. Accordingly, the detoxification enzymes activity were 4.27 times for total esterase, 3.4 for $\mathrm{CE}$ and 3.75 for GST higher in ES population compared with LS strain.

Esterase analysis Among seven identified esterase loci, five loci were migrated to cathode and two for anode (Figure 2).

Table 1: Susceptibility of Sitopilus oryzae adults to the tested insecticides after $24 \mathrm{hr}$ exposure.

\begin{tabular}{lccccccccc}
\hline Insecticide & Strain & $\begin{array}{c}\mathbf{L C} \\
\mathbf{m g} \backslash \mathbf{I}\end{array}$ & $\begin{array}{c}\text { Confidence } \\
\text { limits }\end{array}$ & $* \mathbf{R R}_{\mathbf{5 0}}$ & $\begin{array}{c}\mathbf{L C} \mathbf{9 0} \\
\mathbf{m g} / \mathbf{l}\end{array}$ & $\begin{array}{c}\text { Confidence } \\
\text { limits }\end{array}$ & $* * \mathbf{R R}_{\mathbf{9 0}}$ & $\begin{array}{c}\text { Slope } \\
\pm \text { variance }\end{array}$ & Chi $^{\mathbf{2}}$ \\
\hline \multirow{2}{*}{ Cypermethrin } & LS & 2.960 & $2.40-3.69$ & -- & 17.43 & $10.91-36.96$ & -- & $1.68 \pm 0.25$ & 1.897 \\
\cline { 2 - 11 } Deltamethrin & EB & 5.030 & $3.61-8.09$ & 1.79 & 172.58 & $61.66-1187.63$ & 9.90 & $0.85 \pm 0.14$ & 1.72 \\
\hline & LS & 0.230 & $0.15-0.33$ & -- & 7.68 & $5.22-12.5$ & -- & $0.84 \pm 0.07$ & 0.33 \\
\cline { 2 - 11 } Permethrin & EB & 1.197 & $0.82-1.50$ & 5.20 & 22.86 & $13.85-48.67$ & 2.98 & $1.00 \pm 0.11$ & 7.29 \\
\hline \multirow{2}{*}{ Malathion } & LS & 0.778 & $0.58-0.99$ & -- & 9.35 & $6.59-15.18$ & -- & $1.19 \pm 0.12$ & 3.12 \\
\hline & EB & 0.720 & $0.56-0.89$ & 0.93 & 8.71 & $6.20-13.81$ & 0.93 & $1.18 \pm 0.11$ & 3.33 \\
\hline
\end{tabular}

LS: Laboratory-susceptible strain

EB: El-Behera strain

$* \mathrm{RR}_{50}=$ Resistance ratio ( $\mathrm{LC}_{50}$ of the EB strain/LC $\mathrm{L}_{50}$ of $\mathrm{LS}$ strain)

$* * \mathrm{RR}_{90}=$ Resistance ratio ( $\mathrm{LC}_{90}$ of the $\mathrm{EB}$ strain $/ \mathrm{LC} \mathrm{C}_{90}$ of $\mathrm{LS}$ strain)

Table 2: Total esterase, acetylcholinesterase, carboxylesterse and Glutathion $S$-tranferase activity in Sitopilus oryzae adults of both laboratory- susceptible (LS) and El-Behera field strains(EB).

\begin{tabular}{|c|c|c|c|}
\hline \multirow{3}{*}{ Emzyme } & \multicolumn{2}{|c|}{ Strain } & \multirow{3}{*}{$\mathbf{A} \mathbf{R} * *$} \\
\hline & $\mathbf{L S}$ & EB & \\
\hline & $\begin{array}{l}\text { Specific activity* } \\
( \pm \text { SE })\end{array}$ & $\begin{array}{l}\text { Specific activity* } \\
( \pm \text { SE })\end{array}$ & \\
\hline Total esterase & $1.23 \times 10^{-2}\left(0.1 \times 10^{-3}\right)$ & $5.30 \times 10^{-2}\left(5.1 \times 10^{-4}\right)$ & 4.23 \\
\hline Acetyle- cholinesterase & $8.41 \times 10^{-4}\left(4.1 \times 10^{-5}\right)$ & $2.96 \times 10^{-3}\left(6.8 \times 10^{-5}\right)$ & 3.52 \\
\hline Carboxylesterase & $1.16 \times 10^{-3}\left(2.2 \times 10^{-5}\right)$ & $3.95 \times 10^{-3}\left(1.1 \times 10^{-4}\right)$ & 3.40 \\
\hline Glutathion $S$ - transferase & $6.44 \times 10^{-3}\left(1.0 \times 10^{-3}\right)$ & $2.42 \times 10^{-2}\left(5.0 \times 10^{-4}\right)$ & 3.75 \\
\hline
\end{tabular}

*Specific activity $=\Delta \mathrm{OD} / \mathrm{mg}$ protein $/ \mathrm{min}$

**AR=Specific activity of EB strain/Specific activity of LS strain 


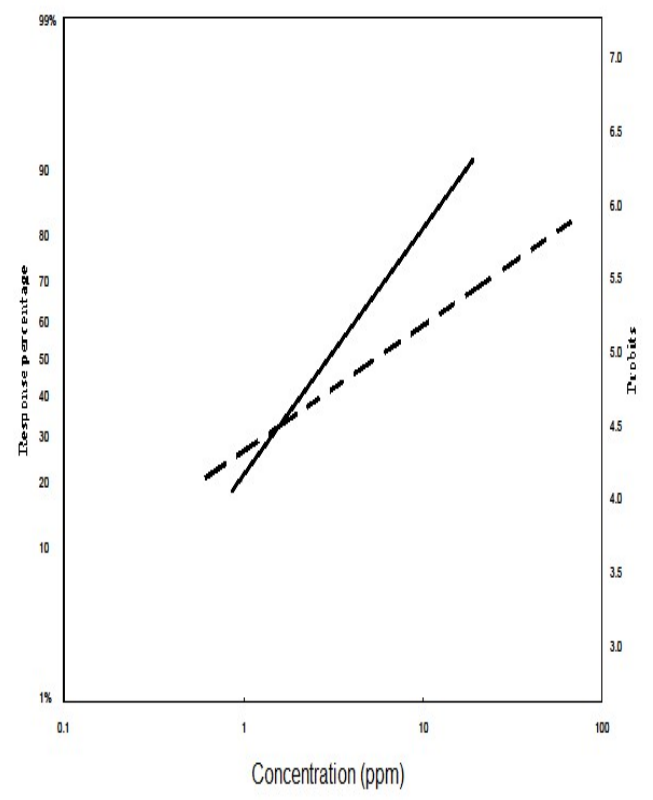

Cypermethrin

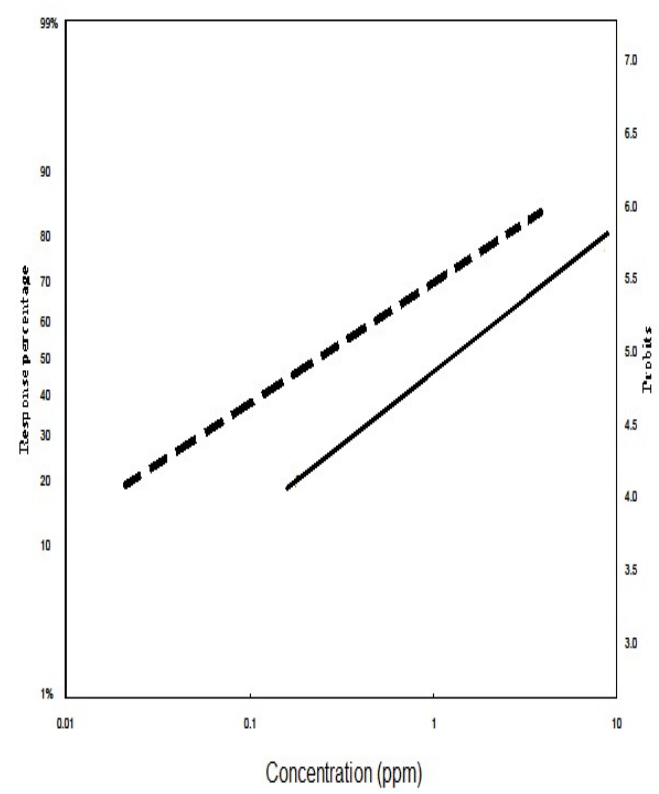

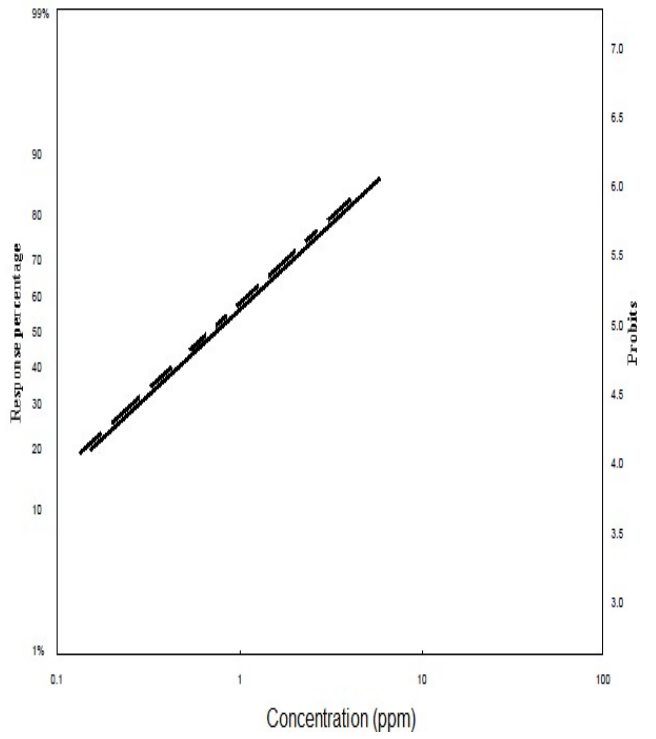

Permethrin

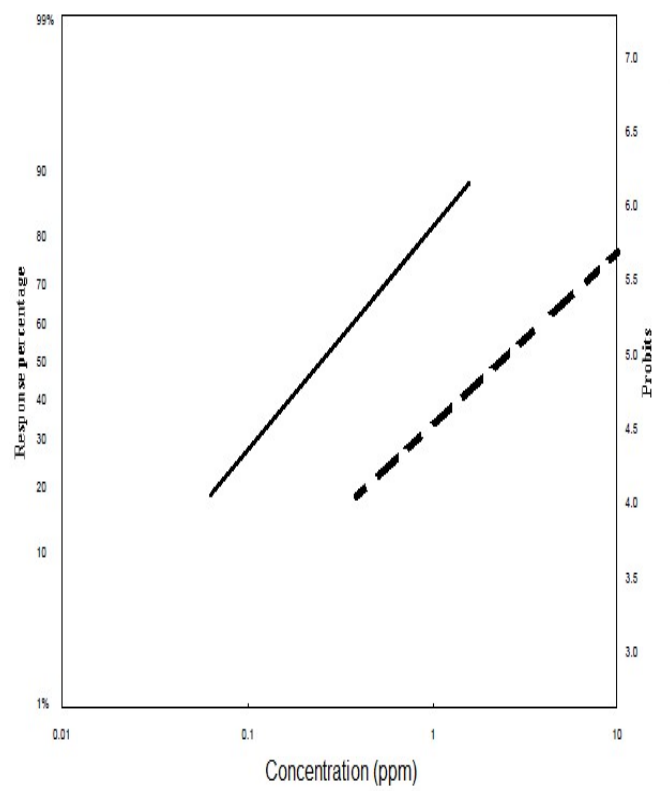

Malathion

Deltamethrin

Figure 1: Ld-p lines of Sitophilus oryzae adults to the tested insecticides Laboratory- Susceptible strain (_ $)$ and El- Behera strain (- - -) 


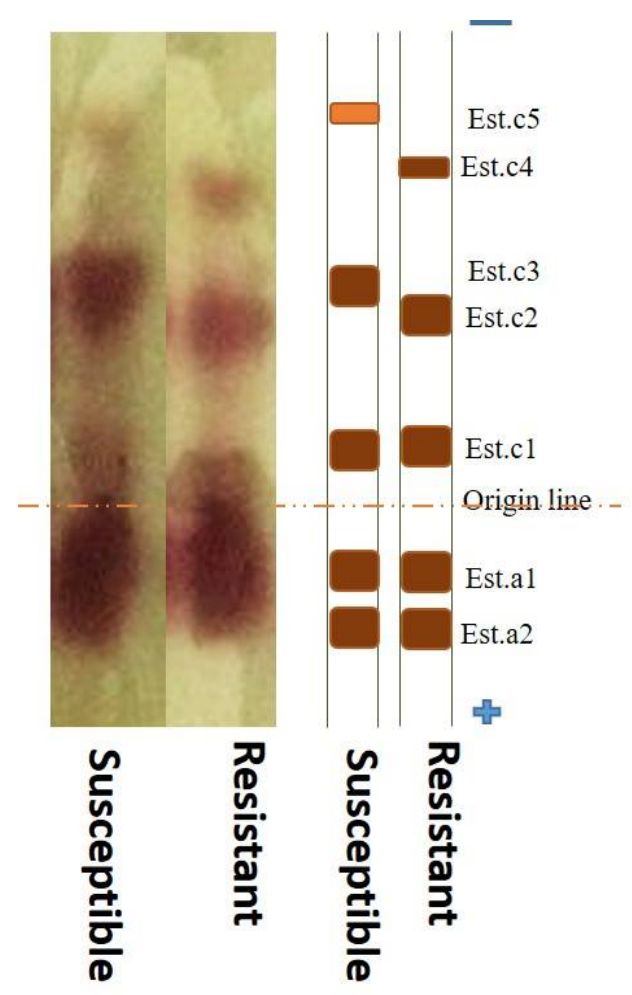

Figure 2: Esterase isozymes profile of Sitophilus oryzae adult of the laboratory susceptible (LS) and ElBehera (EB) field strains (Agar-starch-polyvinyl pyrolidine electrophoresis gel stained with $\alpha$ and $B$ naphthyl acetate).

A common locus (Est1) was detected for all samples. Although, an extra locus (Est5) was detected in the LS weevils' pattern compared with the resistant EB weevils, both strains were sharing four loci (Est.1, Est.2, Est.3 and Est.4) in the cathode direction. On the other hand, in the anode direction, two loci were identified in both strains pattern. In addition, variance in the staining intensity was observed between both strains and the loci size, noticeably, the staining intensity was darker in the resistant strain compared with the susceptible one.

\section{DISCUSSIONS}

According to bioassay data, ES strain developed resistant to malathion and vigor tolerance to deltamethrin but not to permethrin and only marginally to cypermethrin. Similarly, previous studies demonstrated that, $S$. granaries from Aptain, Yugoslavia was resistant to malathion and deltamethrin with $\mathrm{RR}_{50} 4.2$ and 3.4 , respectively, while the same strain was entirely susceptible to cypermethrin (Kljajić and Perić, 2006). Also, resistant to malathion and deltamethrin were observed in $R$. dominica from India (Babu et al, 2017). Distinctly malathion still the most available and acceptable pesticide for grain protection in Egypt (APC, 2017). Although pyrethroids are not incorporated in stored grain protection programs in Egypt, EB strain showed tolerance to deltamethrin and cypermethrin which underline the consequence of wheat importing. As researchers referred the unpredictable resistant distribution of $S$. zeamais Brazilian populations to the trading and local selection (Guedes et al, 1995 and Fragoso et al, 2005). Apparently, the log dosage probit lines (Ldp lines) of EB and LS strains for malathion and deltamethrin were neither parallel nor possessed equal intercepts which suggest an alternation of detoxification enzymes qualitatively, and/or quantitatively or may be dissimilar enzymes involved in the detoxification process in both strains (Hardman et al , 1959 and Kuperman et al , 1961). Furthermore, these Ldp lines showed heterogeneity in EB population which proposes that, resistance is in a developing stage and alerts supposed increase in resistance level on the horizon. Additionally, these data is totally in harmony with the biochemical data, as the relatively high resistance ratios recorded with malathion and deltamethrin could be a consequence of biochemical transformations in EB strain that were observed as elevation in activity of total esterase, CE and GST as well AChE. Insecticide resistance in insects could be referring to three major mechanisms. First, the behavioral mechanism; which occurs as result of conversion in 
insect habits towards the minimum exposure (Hemingway and Ranson, 2000) and (Lee and Lees, 2001). Second, The physiological mechanism that includes the changes in penetration and transportation of the pesticide into the insect body (Scott, 1999). Third, the biochemical mechanism which is representing in metabolic resistance and the target site insensitivity (Gao et al, 2006), (Konuş, 2015). Metabolic resistance includes the elevation or alternation in activity of some enzyme families; mixed function oxidase P450, esterase and glutathione $S$ - transferase that lead to accelerate pesticide detoxification (Paine and Brooke, 2016). The resistance mechanism of elevation or alternation of detoxifying enzymes has contributed to a reduce of the available dose at the target site that is crucial to cause the lethal effect in an insect, while alternation of target site contributes to lose the binding between the insecticide molecule and its target (Panini et al, 2016). Esterase based resistance could be achieved as a result of qualitative and/or quantitative alternation causing enzyme overproduction or modifications of enzyme structure (Oppenoorth and van Asperen, 1960). Both malathion and deltamethrin insecticides could be subjected for hydrolysis by esterase (Konus, 2015) and thus the high activity of esterase which was detected in EB adults suggest that, esterase are involved in malathion and deltamethrin resistance mechanisms in this population. CE was found to attack the carboxylester moiety of malathion molecule (Matsumura and Brown, 1960) thus organophosphate resistance, which refers to $\mathrm{CE}$ is known as specific esterase mechanism. This mechanism was confirmed in most cases of malathion resistance in $T$. castaneum strains (Julio et al, 2017). Moreover, Pyrethroid resistance have been reported to be correlated to esterase in Tribolium castaneum (Dyte and Rowlands 1968) and (Wool and Front 2002). Accordingly, in our case of study we may consider deltamethrin resistance and cypermethrin resistance partly lay on esterase as pyrethroids has been found to be sequestered in the insect's haemolymph as consequence of a high affinity binding site on carboxylesterase (Lee and Clark 1996) and (Boyer et al, 2012). Moreover, esterase analysis indicated high degree of genetic polymorphism between EB and SL populations of $S$. oryzae. The results in line with that reported by (Coelho-Bortolo et al, 2016) in which genetic variance might be attributed to wide geographical distribution and importing of stored product commodities. Esterase isozymes in insects often show large polymorphism that resultant in strong selection pressure such as what was recorded in T. castaneum (Price, 1984) and O. surinamensis (Lee and Lees,2001) and (Silva and Lapenta 2011). Our data suggested that esterase(s) are obviously involved in resistance to malation and deltamethin in EB strain. However, other studies revealed a negative relation between pyrethroid resistance and esterase activity patterns (Han et al, 1998) and( Ali and Turner 2001) accordingly other mechanisms in particularly target site insensitivity may be involved in decreasing susceptibility to deltamethrin and cypermethrin in EB strain (Collins, 1990). The development of resistance in EB strain to cypermethrin and deltamethrin but not to permethrin might be due to their distinct mode of action which also correlated to absence (permethrin) or presence of cyano group (cypermethin and deltamethrin). Furthermore, AChE as a non metabolic resistance known as a target site insensitivity mechanism found to be related to malathion resistance (Guedes and Kun Yan Zhu 1998) and (Lee and Lees 2001). Malathion molecule is a competitive inhibitor analogous to the molecule of Ach, the substrate of $\mathrm{AChE}$ and the resistance mechanism occurs due to mutation in the target protein (Fournier and Mutero, 1994). Also, GST is involved in organophosphoates resistance through O- dealkylation or O-dearylation (Hayes and Wolf 1990) and (Huang et al, 1998) detoxification of metabolites as a minor mechanism (Hemingway et al, 1991) and dehydrochlorination (Clark and Shamaan, 1984). While dissimilar mechanisms found to be associated with pyrethroid resistance since GST eliminate lipid peroxidation products which is initiated by pyrethroids via preventing oxidation which is the reason of insect damage (Vontas et al., 2001) and/or through a sequestration mechanism by binding pyrethroid molecules (Kostaropoulos et al, 2001). Moreover, GST may have a role as binding proteins increasing the activity of other detoxifying enzymes as esterase (Grant and Matsumura 1989) and (Kostaropoulos et $a l, 2001)$. In conclusion, this study results indicated that EB population developed resistance to malathion, deltamithrin and slightly to cypermethin but not to permetrin. There was genetic polymorphism between EB and SL populations. These changes and the resistance appear to be directly related to selection pressure due to continuous application of malathion and ultimately related to wheat importing. The mechanism of resistance suggested being biochemical alteration. These results suggest that EB population became resistant but the resistance is still in its developing stages which underline the importance of periodic monitoring as the foremost step in pest control. However, further studies using synergists and molecular techniques are required to determine the specific resistance mechanism and the possible countermeasures precisely. 


\section{REFERENCES}

Ali, N. and B. Turner (2001). Allozyme polymorphism and variability in permethrin tolerance in British populations of the parthenogenetic stored product pest Liposcelis bostrychophila (Liposcelididae, Psocoptera). J. Stored Prod. Res. 37, 111-125.

APC (2017). Agricultural Pesticides Committee. Recommendations adopted to control agricultural pests Ministry of Agriculture and Land Reclamation.

APRD (2017). Arthropod Pesticide Resistance Database Cited from:https://www.pesticideresistance.org/inde x.php

Athanassiou, C.G., A.S. Papagregoriou and C.T. Buchelos (2004). Insecticidal and residual effect of three pyrethroids against Sitophilus oryzae (L.) (Coleoptera: Curculionidae) on stored wheat. J. Stored Prod. Res. 40, 289297.

Babu, S.R, D.V. Sai Ram Kumar, C.H. Naga Satya Sri and T. Madhumathi (2017). Evaluation of spinosad against malathion and deltamethrin resistant population of lesser grain borer, Rhyzopertha dominica in Andhra Pradesh, India. Int. J.Curr. Microbiol. App.Sci.,6(6): 165-171.

Beeman, R.W., S.M. Nanis (1986). Malathion resistance alleles and their fitness in the red flour beetle. J. Econ. Entomol., 79:580-587.

Boyer, S., H. Zhang, G. Lempérière (2012). A review of control methods and resistance mechanisms in stored-product insects. Bull. Entomol. Res., 102: 213-229.

CABI (2017). Sitophilus oryzae ( rice grain weevil), invasive species compendium datasheets. Cited

from:http://www.cabi.org/isc/datasheet/10887 \#tab2?nav.

Clark, A.G. and N.A.Shamaan (1984). Evidence that DDT-dehydrochlorinase from the house fly is a glutathione S-transferase. Pestic. Biochem. Physiol., 22: 249-261.

Coelho-Bortolo, T., C.A. Mangolin and A.S. Lapenta (2016). Genetic variability in the natural populations of Lasioderma serricorne (F.) (Coleoptera: Anobiidae), detected by RAPD markers and by esterase isozymes. Bull. Entomol. Res., 106: 47-53.

Collins, P.J. (1990). A new resistance to pyrethroids in Tribolium castaneum (Herbst). Pestic. Sci., 28: 101-115.

Dyte, C.E. and D.G. Rowlands (1968). The metabolism and synergism of malathion in resistant and susceptible strains of Tribolium castaneum (Coleoptera: Tenebrionidae). J. Stored Prod. Res., 4: 157-173.
Ellman, G.L., K.D. Courtney, V. Andres and R.M. Featherstone (1961). A new and rapid colorimetric determination of acetylcholinesterase activity. Biochem. Pharmacol., 7: 88-95.

FAO (1974). Food and Agriculture Organization. Recommended methods for the detection and measurement of resistance of agricultural pests to pesticides: Tentative method for adults of some major beetle pests of stored cereals with malathion or lindane. FAO method no. 15. Plant Prot. Bull., 22: 127-138.

FAO (2006). Food and Agriculture Organization. Policy Brief: Food security and wheat policy in Egypt, 2000 (8) policy brief No. 2.

FAO (2015), Food and Agriculture Organization. Egypt wheat sector review.

Finney, D.J. (1971). Probit analysis. Third edition. Cambridge University press, Cambridge, UK.

Fournier, D. and A. Mutero (1994). Modification of acetylcholinesterase as a mechanism of resistance to insecticides. Comp. Biochem. Physiol. Part C Pharmacol., 108: 19-31.

Fragoso,L D.B., R.N.C Guedes .and L.A. Peternelli (2005). Developmental rates and population growth of insecticide- resistant and susceptible populations of Sitophilus zeamais. J. Stored Prod. Res., 41: 271-281.

Gao, J.-R., K.S. Yoon, R.K. Frisbie, G.C. Coles, and J.M. Clark (2006). Esterase-mediated malathion resistance in the human head louse, Pediculus capitis (Anoplura: Pediculidae). Pestic. Biochem. Physiol., 85: 28-37.

Grant, D.F. and F. Matsumura, (1989). Glutathione S-transferase 1 and 2 in susceptible and insecticide resistant Aedes aegypti. Pestic. Biochem. Physiol., 33: 132-143.

Guedes R.N.C., J.G. Lima, J.P. Santos and C.D. Cruz (1995). Resistance to DDT and pyrethroids in Brazilian populations of Sitophilus zeamais Motsch. (Coleoptera: Curculionidae). J. Stored Prod. Res., 31: 145150.

Guedes, R.N.C. and K. Y. Zhu, (1998). Characterization of malathion resistance in a Mexican population of Rhizopertha dominica. Pestic. Sci., 53:15-20.

Hagstrum, D.W. and T.W Phillips (2017). Evolution of stored-product entomology: Protecting the world food supply. Annu. Rev. Entomol., 62: 379-397.

Han, Z., G.D. Moores, I. Denholm, and A. L. Devonshire (1998). Association between biochemical markers and insecticide resistance in the cotton aphid, Aphis gossypii Glover. Pestic. Biochem. Physiol., 62: 164 171. 
Hardman, H. F., J. I. Moore, and B.K.B. Lum (1959). A method for analyzing the effect of $\mathrm{pH}$ and ionization of drugs upon cardiac tissue with special reference to pentabarbitol,. J. Pharmacol. Exp. Ther., 126:136.

Hayes, J.D. and C.R. Wolf (1990). Molecular mechanisms of drug resistance. Biochem. J., 272: 281-295.

Heather, N.W. (1986). Sex-linked to pyrethroids. J. Stored Prod. Res., 22 (1): 15-20.

Hemingway, J., J. Miyamoto and P.R.J. Herath (1991). A possible novel link between organophosphorus and DDT insecticide resistance genes in Anopheles: Supporting evidence from fenitrothion metabolism studies. Pestic. Biochem. Physiol., 39:49-56.

Hemingway, J., H. Ranson (2000). Insecticide resistance in insect vectors of human disease. Annu. Rev. Entomol., 45: 371-91.

Huang, H.S., N.T. Hu, Y.E. Yao, C.Y. Wu, S.W. Chiang and C. N. Sun, (1998). Molecular cloning and heterologous expression of a glutathione S-transferase involved in insecticide resistance from the diamondback moth, Plutella xylostella. Insect Biochem. Mol. Biol., 28: 651-658.

Julio, A.H.F., A.A.S. Gigliolli, K.A.K. Cardoso, S.D. Drosdoski,R.A. Kulza, F.AV. Seixas, M.C.C. Ruvolo-Takasusuki, C.G.M. de Souza, and A.S. Lapenta (2017). Multiple resistance to pirimiphos-methyl and bifenthrin in Tribolium castaneum involves the activity of lipases, esterases, and laccase2. Comp. Biochem. Physiol. Part - C Toxicol. Pharmacol., 195: 27-43.

Kljajić, P., I. Perić (2006). Susceptibility to contact insecticides of granary weevil Sitophilus granarius (L.) (Coleoptera: Curculionidae) originating from different locations in the former Yugoslavia. J. Stored Prod. Res., 42: 149-161.

Kljajic, P., I. Peric (2007). Effectiveness of wheatapplied contact insecticides against Sitophilus granarius (L.) originating from different populations. J. Stored Prod. Res., 43: 523529.

Kljajić, P., I. Perić (2009). Residual effects of deltamethrin and malathion on different populations of Sitophilus granarius (L.) on treated wheat grains. J. Stored Prod. Res., 45: 45-48.

Konus, M. (2015). Malathion resistance mediated by detoxification enzymes in Sitophilus zeamais (motschulsky) (Coleoptera: Curculionidae). Fresenius Environ. Bull., 24:2146-2151.
Kostaropoulos, I., A.I. Papadopoulos, A. Metaxakis, E. Boukouvala, and E. PapadopoulouMourkidou (2001). Glutathione S-transferase in the defence against pyrethroids in insects. Insect Biochem. Mol. Biol., 31: 313-319.

Koura, A. and M.A. El-Halfawy (1972). Weight loss in stored grains caused by insect infestation in Egypt. Bull. la Soc. Entomol. d'Egypte. 56: 413-417.

Kuperman, A. S., E.W. Gill and W. F. Riker, (1961). The relationship between cholinesterase inhibition and drug-induced facilitation of mammalian neuro- muscular transmission,. J. Pharmacol. Exp. Ther., 132: $65-73$.

Lee, S., and J.M. Clark (1996). Tissue distribution and biochemical characterization of carboxylesterases associated with permethrin resistance in a near isogenic strain of Colorado potato beetle. Pestic. Biochem. Physiol., 56: 208-219.

Lee, S.E., and E.M. Lees (2001). Biochemical mechanisms of resistance in strains of Oryzaephilus surinamensis (Coleoptera: Silvanidae) resistant to malathion and chlorpyrifos-methyl. J. Econ. Entomol., 94:706-13.

Lowry, O.H., N.J. Rosebrough, A.L. Farr, and R.J. Randall (1951). Protein measurement with the Folin phenol reagent. J. Biol. Chem., 193: 265-75.

Matsumura, F., and A.W.A Brown (1960). Biochemistry of malathion resistance in Culex tarsalis. J. Econ. Entomol., 54: 1176-1185.

Mendoza, C E, J, B.Shields and W.E.R.J. philipps (1971). Distribution of carboxylesterase activities in different tissues of albino rats. Comp. Biochem. Physiol., 40 B (1): 841-854.

Oppenoorth, F.J., and K. van Asperen (1960). Allelic genes in the housefly producing modified enzymes that cause organophosphate resistance. Sci., 132: 298-299.

Paine, M.J.I., and B. Brooke (2016). Insecticide resistance and its impact on vector control, In: Advances in insect control and resistance management. Springer, pp. 287-312.

Panini, M., G. Manicardi, G. Moores and E. Mazzoni (2016). An overview of the main pathways of metabolic resistance in insects. ISJ - Inv. Surv.1 J., 13: 326-335.

Price, N.R., (1984). Active exclusion of phosphine as mechanism of resistance in Rizopertha dominica (F.) (Coleoptera: Bostrychidae). J. Stored Prod. Res., 20: 163-168.

Scott, J.G. (1999). Cytochromes P450 and insecticide resistance. Insect Biochem. Mol. Biol., 29: 757-77. 
Shaw, C.R. and R. Prasad (1970). Starch gel electrophoresis of enzymes-A compilation of recipes. Biochem. Genet., 4: 297-320.

Silva, G. R. and S. Lapenta (2011). Genetic variability in esterases and the insecticide resistance in Brazilian strains of Oryzaephilus mercator and Oryzaephilus surinamensis (Coleoptera: Silvanidae). Bull. Entomol. Res., 101: $177-85$.

Strong, R.G., D.E. Sbur and G.J. Partida (1967). Rearing stored-product insects for laboratory studies - lesser grain borer granary weevil rice weevil Sitophilus zeamais and angoumois grain moth. J. Econ. Entomol., 60: 10781082.

Van Asperen, K. (1962). A study of housefly esterases by means of a sensitive colorimetric method. J. Insect Physiol., 8: 401-416.

Vessey,D.A. and T.D. Boyer (1984). Differential activation and inhibition of different forms of rat liver glutatione $\mathrm{S}$-transferase by the herbicides 2,4,5-dichlorophenoxyacetate (2,4,5-D)and (2,4,5-trichorophenoxyacetate (2,4,5-T). Toxicol. Appl. Pharmacol., 73(3): 492-499.
Vontas, J.G., G.J. Small and J. Hemingway (2001). Glutathione S-transferases as antioxidant defence agents confer pyrethroid resistance in Nilaparvata lugens. Biochem. J., 357: 65-72.

Wally, A. (2014). Egypt grain feed annual: Wheat demand expands, Corn stays steady and there's continued reluctance to export rice. GAIN Report, USDA foreign agriculture service. Global agriculture network. Available from:

https://gain.fas.usda.gov/Recent $\% 20 \mathrm{GAIN} \% 2$ 0Publications/Grain $\% 20$ and $\% 20$ Feed $\% 20$ Ann ual Cairo Egypt 5-5-2014.pdf [Accessed: 2 Oct 2017]

Wool, D. and L. Front (2002). Esterase variation in Tribolium confusum (Coleoptera: Tenebrionidae): Genetic analysis of interstrain crosses in relation to malathion resistance. J. Stored Prod. Res., 39: 237-249.

Zettler J. (1974). Malathion resistance in Tribolium castaneum collected from stored peanuts. J. Econ. Entomol., 67: 339-40. 


\section{الملخص العربي}

\section{حالة المقاومة فى سوسة الأرز لبعض المبيدات الحشرية و الميكانيكيات المرتبطة بها \\ منال أحمد عطية'، تر انديل فايز وهبه'، مروة إبراهيم مقلد"، محمد سالم شعويرَّ

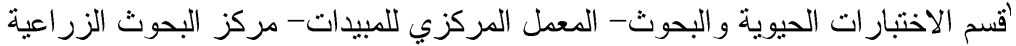

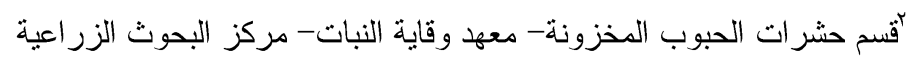

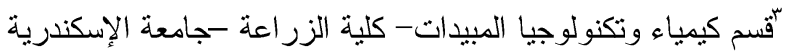

تم تجميع سوسة الأرز من محافظه البحيرة. و عند مقارنة سمية بعض المبيدات المختبرة لتلاكك الـسلالة مقارنـــة

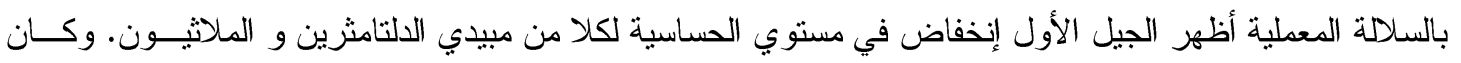

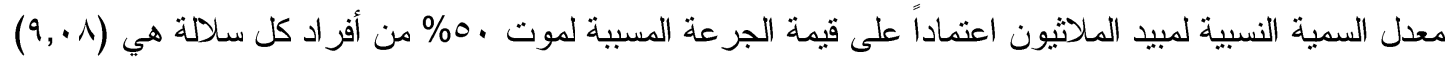

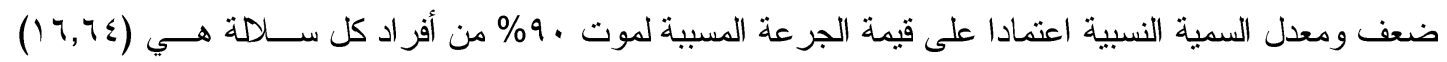
ضعف بالمقارنة بالسلالة الحساسة. كما أظهرت سلالة البحيرة تحمل لمبيد الدلتامثرين حيث كان معدل السمية النسبية

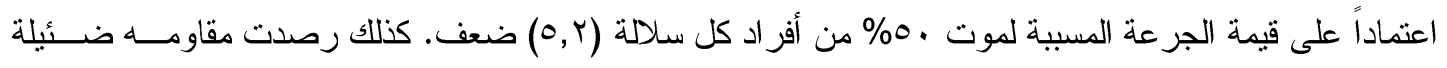

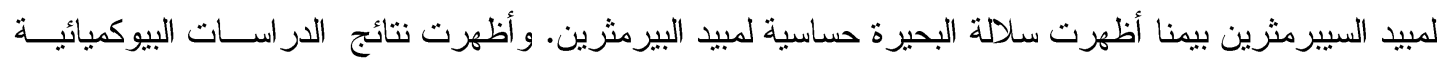

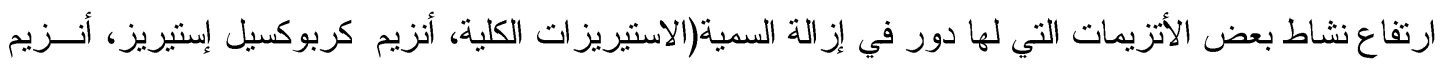

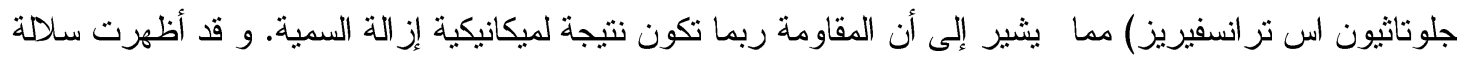

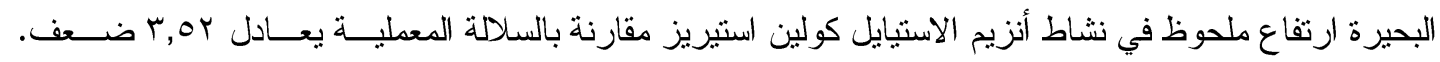

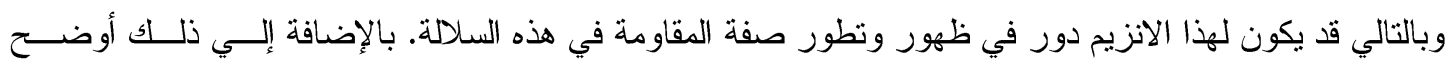
بروفيل الاستيريز وجود بعض التغيرات الور اثثية بين سلالة البحيرة و السلالة المعلية وربما يعزي ذلك إلي الضغط

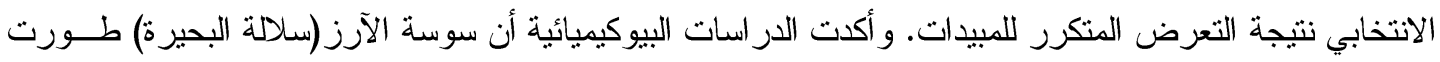

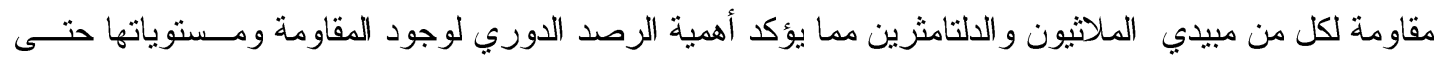
يمكن التدخل بالبر امج الفعالة لمكافحة سوسة الأرز و غير ها من الآفات الحشرية التي تهاجم الحبوب المخزونة. 